\title{
Habitat Segregation in Aster subulatus and Three Species of Erigeron Due to Soil Moisture*
}

\author{
by Akira MiYawaki**
}

宮脇 眧：土壤水分によるハハキギクとアレチノギク属植物の寸久文わ

Received January 26, 1955

\section{Introduction}

As a means of ecological analysis of the structure of weed communities, the concept of habitat segregation becomes the most important problem to be solved.

The phenomenon of habitat segregation of weeds is divided into two groups based on their relationship between the life form and the growing field of plants. The one is the homogenous habitat segregation and the other is the heterogenous, habitat segregation. The former is that in which the same species occurs in different life forms and different habitats, while the latter is that in which some different species occur in different habitats and, in many cases in, different life forms ${ }^{3}$.

The purpose of the present paper is to investigate ecologically and morphologically a heterogenous habitat segregation between Aster subulatus Michx, and the three species of Erigeron (E. sumatrensis Retz, E. canadensis L. and E. bonariensis L.), both of which belong to the same life form and growing period, and also to investigate a homogenous habitat segregation in $A$. subulatus.

The author wishes to express his gratitude to Professor Y. Horikawa of the Hiroshima University for suggesting this investigation as well as for constant guidance throughout the course of the work. To Professor Y. Ogura of the Tokyo University, the author is indebted for much valuable advices on the morphological and anatomical work. Further the author owes thanks to Dr. S. Watari of the Tokyo University, Professor M. Kitagawa of the Yokohama National University, Assist. Professor H. Suzuki and Lecturer H. Andô of the Hiroshima University for their helps and valuable suggestions. Thanks are also due to Professor H. Yagi of the Agricultural Institute of the Yokohama National University for all possible help in providing room and apparatus in the time of the soil analyses.

\section{Area and Method of Study}

Field surveys were carried out at the growing habitats of Aster subulatus and

*1) Read on the 18th annual meeting of the Botanical Society of Japan, October, 1953 at Kanazawa University, Kanazawa City. 2) Supported by a Grant in Aid for Development Scientific Research from the Ministry of Education in 1953.

** Biological Institute, Faculty of Liberal Arts, the Yokohama National University. 
Erigeron spp. on the wayside, ditch-wall and vacant ground in Sendamachi, Hiroshima city in the summer of 1951, '52 and '53.

1). Study of vegetation: Analyses of plant communities of $A$. subulatus and Erigeron spp. on road-sides and ditch-walls were made by the systematic sampling by belt transects of $0.2-1.0 \mathrm{~m}$ in width or quadrats of $1.0 \mathrm{~m}^{2}$. Ecological features of the communities were expressed by the floristic list, coverage and frequency of the occurring plants.

2). Examination of the bed soil of communities: The water content of bed soil at the road-side communities and the pure communities was considered with respect to the soil sample of $20 \mathrm{~g}$ and measured after the dryness at $110 \mathrm{C}^{\circ}$ for 20 hours. For the pure communities, the chemical components of bed soil were determined, too. In this determination, total nitrogen and humus were measured by the Kjeldahl's method and the Turin's method respectively, and in the other tests of soil was made use of the Prof. Yagi's soil tester.

3). Morphological study of subterraneous parts of A. subulatus: The subterraneous parts of $A$. subulatus in its pure communities and in the Erigeron communities were studied morphologically and anatomically for the comparison in both communities.

\section{Data and Discussion}

I. Heterogenous habitat segregation between $A$. subulatus and three species of Erigeron:

1) Roadside communities and their soil moisture

For the vegetation developed in and by a green belt zone of road in front of the Western gate of the Hiroshima University, investigations were carried out in September, 1951. To facilitate the investigation, the vegetation was divided into 7 transversal zones $\mathbf{A} \sim \mathbf{E}$ from a physiognomical view point (Fig. 1, Tab. I). At the A zone $(0.3 \mathrm{~m}$ in width) nearer to the side of the high speed vehicle road-way, $A$. subulatus is most dominant in coverage and frequency. But the opposite B' zone is dominated by $E$. sumatrensis and is very few in $A$. subulatus. On the $\mathbf{C}, \mathbf{C}^{\prime}$, and $\mathbf{D}$

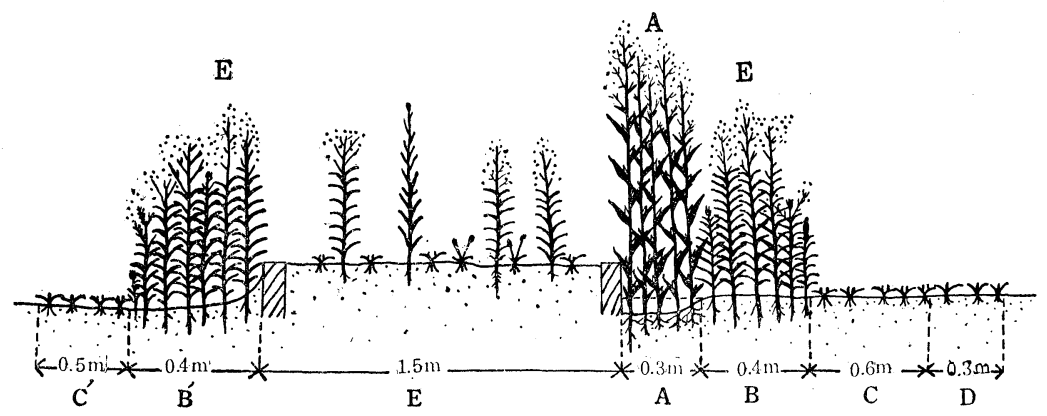

Fig. 1. Diagramatic beisect through a green belt zone vegetation A, Aster subulatus; E, Erigeron spp. 
zones which are adjoined to the bare land and influenced by the traffic of vehicles, Digitaria ascendens Henr., D. violascens Link. and Eleusine indica Gaerten are abundant ${ }^{3)}$.

As to the topography of the habitat, the road-surface is generally flat, but the high speed vehicle way is slightly convex and is a little depressed at the adjoined to the green zones. Namely, the part touching the green kelt zone exhibits a slope of $5^{\circ}$ to $10^{\circ}$ at the place of $0.3-0.4 \mathrm{~m}$ apart from the paving-stone (near the boundaryline between $\mathbf{A}$ and $\mathbf{B}$ zones) and is favoured with the richness of soil moisture and rubbish. On the other hand, the opposite $\mathbf{B}^{\prime}$ zone is subjected to the accumulation of soil and slightly raised. In consequence, rain-water on the B' zone runs down to the opposite edge of the road:

Table I. Structure of the vegetation in and by a green belt zone in the 113 road-way at Sendamachi, Hiroshima city (showing coverage and frequency obtained from the 10 quadrats with $1 \mathrm{~m}^{2}$ area in each zone)

\begin{tabular}{|c|c|c|c|c|c|c|c|}
\hline $\begin{array}{c}\text { Division of } \\
\text { Vegetation } \\
\text { Species }\end{array}$ & C. A. Fq. & $\begin{array}{l}\text { B } \\
\text { C. d. Fq. }\end{array}$ & $\begin{array}{l}\text { B' } \\
\text { C. d. Fq. }\end{array}$ & $\begin{array}{l}\text { C } \\
\text { C. d. Fq. }\end{array}$ & $\begin{array}{l}\text { C' } \\
\text { C. d. Fq. }\end{array}$ & $\begin{array}{c}\text { D } \\
\text { C. d. Fq. }\end{array}$ & C. d. Fq. \\
\hline Aster subulatus & $5.0 \quad 100$ & 0.7 & - & - & - & - & 一 \\
\hline Erigeron sumatrensis & 0.7 & 4.1100 & 4.6100 & 一 & 一 & - & 1.0 \\
\hline E. canadensis & 0.7 & $3.7 \quad 100$ & 2.190 & $0.2 \quad 20$ & 一 & 一 & 2.6 \\
\hline$E$ bonariensis & 0.2 & $3.2 \quad 90$ & $2.0 \quad 80$ & $0.2 \quad 10$ & 一 & 一 & 1.2 \\
\hline Cynodon Dactylon & 1.3 & 1.0 & 一 & 1.130 & - & 0.6 & - \\
\hline Setaria viridis & 0.2 & 0.5 & $0.1 \quad 10$ & $0.3 \quad 20$ & 一 & 一 & $1.0 \quad 10$ \\
\hline Euphorbia sapina & $0.2 \quad 10$ & - & $0.2 \quad 10$ & - & - & - & - \\
\hline Polygonum longisetum & 0.1 & - & 一 & - & 一 & 一 & - \\
\hline Kummerovia striata & 一 & $0.1 \quad 10$ & 一 & 一 & - & 一 & 一 \\
\hline Cyperus rotundus & - & $0.3 \quad 10$ & - & - & $0.3 \quad 10$ & - & - \\
\hline Digitaria ascendens & - & $0.5 \quad 40$ & $0.2 \quad 10$ & $1.2 \quad 30$ & - & $0.2 \quad 20$ & $1.7 \quad 70$ \\
\hline D. violascens & - & - & $2.0 \quad 80$ & $4.6 \quad 100$ & $0.9 \quad 50$ & $0.8 \quad 50$ & $4.2 \quad 100$ \\
\hline Eleusine indica & 一 & - & $0.2 \quad 20$ & 1.270 & 4.9100 & 4.6100 & 一 \\
\hline Eragrostis multicaulis & - & 一 & - & - & 一 & 0.1 & 一 \\
\hline
\end{tabular}

The results of the determination of soil water content were shown in Tab. II. From this table it is apparent that the soil water content for the sample on the 8th of September*, which is just before a day of rain-fall, is far smaller in every zone than that on the 11th of Sep., which is two days after the rain-fall day. But in both cases, there can be seen a remarkable difference between $E$. sumatrensis-zone (B, B') and $A$. subulatus-zone (A), the latter of which has the highest water content.

2) Analysis of ditch wall community

In Sendamachi of Hiroshima city, there is a ditch which is about $5 \mathrm{~m}$ in width and $2.6 \mathrm{~m}$ in depth. The water level of the ditch is always changeable and shows a conspicuous rise even when it encounters a very small rain-fall. There grows a

* While the investigation was going on in 1951, the rainfall was very little from the 17 th July to the 10th September. 
Table II. Soil water content of each zone in and by a green belt zone showing the mean value of three samples in each zone, and the depth of soil sample portion $10 \mathrm{~cm}$

\begin{tabular}{|c|c|c|c|c|c|c|c|}
\hline Division of vegetation & A & $\mathrm{B}$ & $\mathrm{B}^{\prime}$ & $\mathrm{C}$ & $C^{\prime}$ & $\mathrm{D}$ & E zone \\
\hline Just before rain.fall the 9 th Sep. '51 & 7.5 & 5.9 & 5.4 & 4.5 & 4.4 & 4.5 & $3.4 \%$ \\
\hline Soon after rain-fall the 11 th Sep. ' 51 & 17. 7 & 15.1 & 14.6 & 11.9 & 13.1 & 13.9 & 8.5 \\
\hline
\end{tabular}

dense community of $A$. subulatus and Erigeron spp. on the wall. It is observed at a glance that $A$. subulatus grows near the water's edge and Erigeron spp. becomes more frequent toward higher part of the wall. To analyse the community 22 belt transects, each of which is $0.2 \mathrm{~m}$ in width, were set with every $1 \mathrm{~m}$ interval at right angle to the stream. Furthermore, quadrats of $0.2 \mathrm{~m}^{2}$ were set on each transect and the individual number was carefully investigated with respect to each species. The results are shown in Figs. 2 4. The figures clearly show the heterogenous habitat segregation between $A$. subulatus and Erigeron spp. The communities of the respective genus are separated at the place of $1.8 \sim 2.0 \mathrm{~m}$ high above the water level.

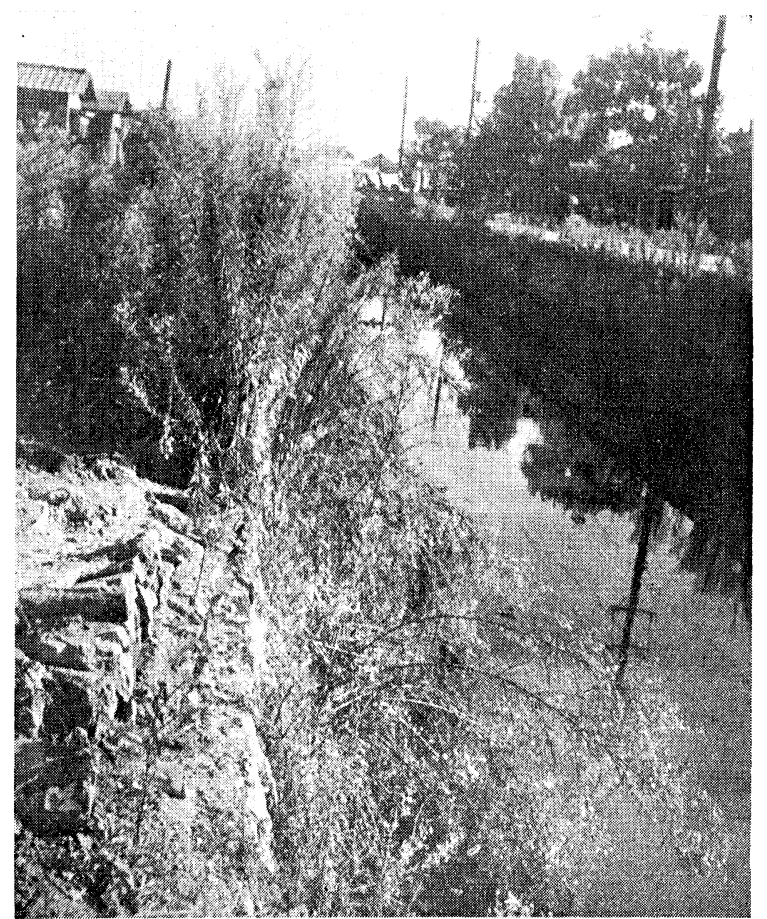

Fig. 2. Ditch wall vegetation constituted with Aster subulatus and three species of Erigeron (the 25th Sep. 1951).

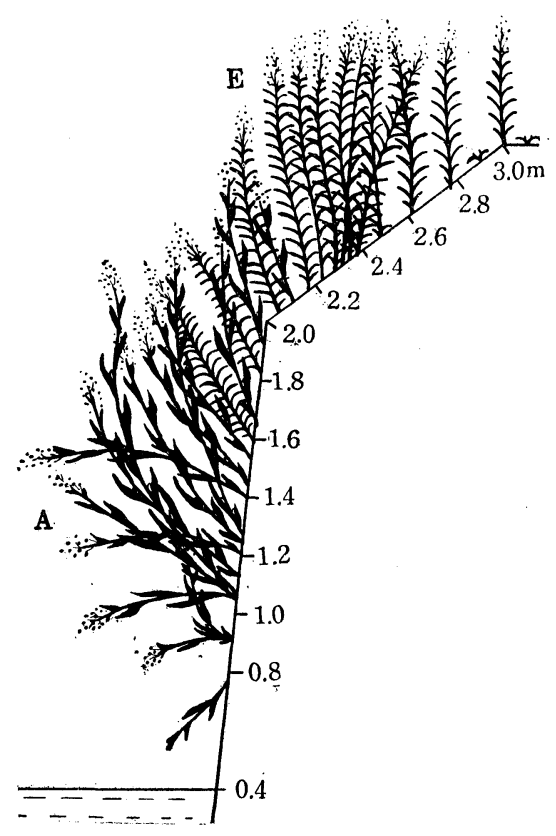

Fig. 3. Diagramatic beisect through a ditch wall vegetation

A, Aster subulatus
E, Erigeron spp.

3) The pure communities at vacant ground

a. A comparison between accompaning species. In each of the pure communities of $A$. subulatus and of E. sumatrensis, 10 quadrats of $1 \mathrm{~m}^{2}$ were set accord- 


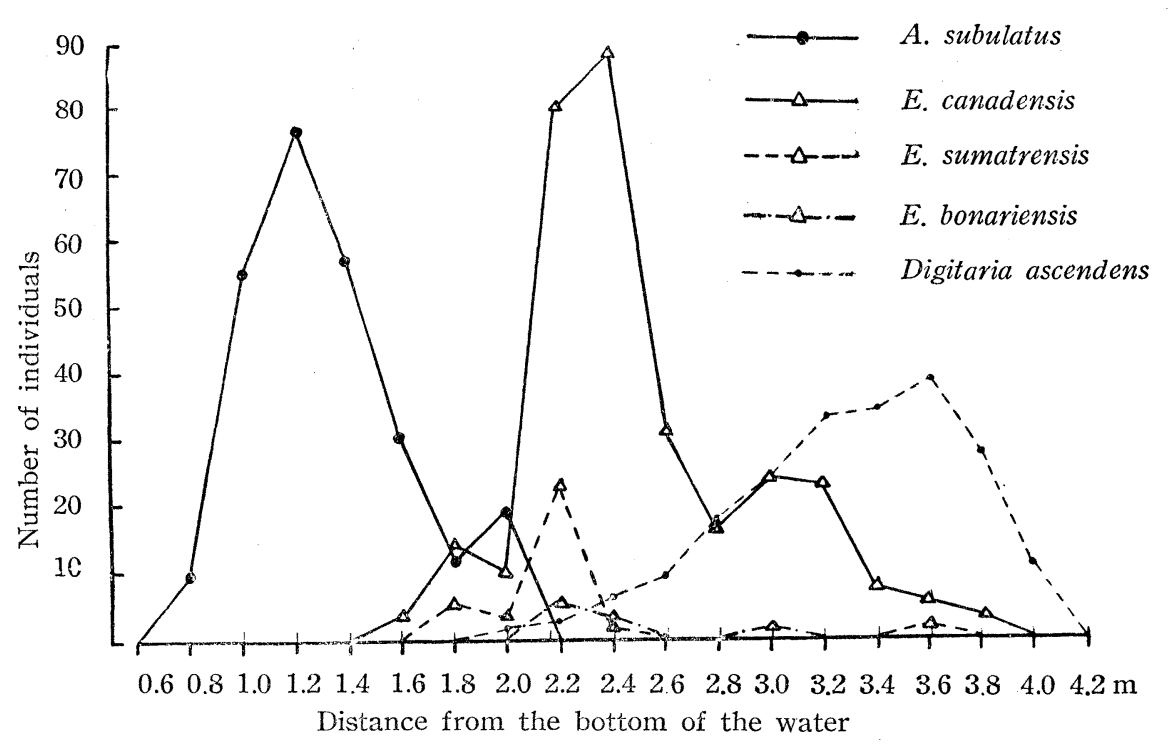

Fig. 4. Micro growing ranges of the main plants on a ditch wall

ing to the systematic sampling, and the accompaning species (which had been divided into 3 groups*: the wetter, middle and drier groups, according to their general character for a soil moisture condition) were compared between the two pure communities with respect to the percentage of species number, coverage and frequency. In the community of $A$. subulatus, the floristic percentage is $47 \%$ in the wetter, $29 \%$ in the middle and $24 \%$ in the drier group, while in the E. sumatrensis community, the wetter group is not found, and the drier one shows such a higher value as $80 \%$. Furthermore, for their total coverage and frequency percentage the same tendency as in the case of the floristic percentage is observed. By the preliminary survey in September 1951 nearly the same results were obtained.

b. Comparison of the chemical components and the water content of the soil between the two communities. As it is clear in Table $\mathrm{V}$, the results of chemical analyses of the soil show not very remarkable differences between the two pure communities in total nitrogen, humus, $\mathrm{pH}, \mathrm{P}_{2} \mathrm{O}_{5}$ and $\mathrm{CaO}$. On the other hand, although the soil belongs to the sandy roam type and humus were very few in both habitats, the maximum water holding capacity as well as the soil water contents both soon after and 3 days after a rain-fall shows higher values in $A$. subulatus community than Erigeron communities.

From the results mentioned above, it becomes clear that the $A$. subulatus and the Erigeron spp, communities exhibit a distinct heterogenous habitat segregation which is due to the soil moisture condition.

* These three groups are not those which are divided according to the so-called plant geographical view point 6,7 ) but comparatively classified ones in view of the weed communities. 
Table. III. A comaprison of accompaning species between two pure communities (I).

\begin{tabular}{|c|c|c|c|c|c|c|c|}
\hline \multirow[b]{2}{*}{ Species } & \multicolumn{3}{|c|}{ A. subulatus community } & \multirow{2}{*}{ Species } & \multicolumn{3}{|c|}{ E. sumatrensis community } \\
\hline & $\begin{array}{l}\text { Character } \\
\text { for moisture }\end{array}$ & C. $\mathrm{d}$. & Freq. & & $\begin{array}{c}\text { Character } \\
\text { for moisture }\end{array}$ & C. d. & Freq. \\
\hline Panicum Crusgalli L. & & & & Digitaria ascendens & $\mathrm{D}$ & 2.2 & 90 \\
\hline var. submutica & $\mathrm{W}$ & 1.8 & 90 & Setaria viridis & $\mathrm{D}$ & 1. 1 & 70 \\
\hline Polygonum longisetum & M & 1.4 & 60 & Trifolium repens & $\mathrm{D}$ & 1.0 & 40 \\
\hline Eclipta prostrata & $\mathrm{W}$ & 0.9 & 50 & Oxalis corniculata & $\mathrm{D}$ & 0.9 & 70 \\
\hline Juncus tenuis & M & 0.8 & 40 & Sagina japonica & $\mathrm{D}$ & 0.6 & 60 \\
\hline Rorippa islandica & $\mathrm{W}$ & 0.6 & 30 & Gnaphalium affine & $\mathrm{D}$ & 0.4 & 40 \\
\hline Polygonum nodosum & M & 0.6 & 40 & Artemisia asiatica & $\mathrm{D}$ & 0.4 & 10 \\
\hline Bidens tripartita & W & 0.5 & 30 & Hydorocotyle martiama & M & 0.3 & 20 \\
\hline Polypogon fugax & $\mathrm{W}$ & 0.4 & 20 & Euphorbia supina & $\mathrm{D}$ & 0.3 & 20 \\
\hline Plantago asiatica & M & 0.4 & 20 & Juncus tenuis & M & 0.3 & 20 \\
\hline Hydrocotyle maritima & M & 0.3 & 10 & Chenopodium album & $\mathrm{D}$ & 0.2 & 20 \\
\hline Digitaria ascendens & $\mathrm{D}$ & 0.2 & 20 & Fatoua villosa & $\mathrm{D}$ & 0.2 & 20 \\
\hline Chenopodium album & $\mathrm{D}$ & 0.2 & 20 & Stellaria neglecta & M & 0.2 & 20 \\
\hline Cyperus microiria & W & 0.2 & 20 & Sonchus oleraceus & M & 0.2 & 20 \\
\hline Alopecurus amurensis & W & 0.1 & 10 & Oxalis Martiana & M & 0.1 & 10 \\
\hline Rumex japonicus & W & 0.1 & 10 & Aster subulatus & & 0.2 & 10 \\
\hline Portulaca oleracea & $\mathrm{D}$ & 0.1 & 10 & Erigeron sumatrensis & & 4.8 & 100 \\
\hline Achyranthes japonica & $\mathrm{D}$ & 0.1 & 10 & E. canadensis & & 2.1 & 80 \\
\hline Aster subulatus & & 5.0 & 100 & E. bonariensis & & 0.5 & 30 \\
\hline Erigeron sumatrensis & & 0.6 & 50 & & & & \\
\hline E. canadensis & & 0.1 & 10 & & & & \\
\hline E. bonariensis & & 0.1 & 20 & & & & \\
\hline
\end{tabular}

W, Wetter; D, Drier and M, Middle group.

Table IV. A comparison of accompanied plants between two pure communities (II).

\begin{tabular}{|l|c|c|c|c|c|c|}
\hline \multirow{2}{*}{$\begin{array}{c}\text { Groups by } \\
\text { character } \\
\text { for moisture }\end{array}$} & \multicolumn{2}{|c|}{ A. subulatus community (17 spp.) } & \multicolumn{2}{|c|}{ E. sumatrensis community (15 spp.) } \\
\cline { 2 - 7 } \cline { 5 - 7 } & $\begin{array}{c}\text { Numb. of } \\
\text { spp. } \%\end{array}$ & $\begin{array}{c}\text { Total } \\
\text { c. d. } \%\end{array}$ & $\begin{array}{c}\text { Total } \\
\text { freq. } \%\end{array}$ & $\begin{array}{c}\text { Numb. of } \\
\text { spp. \% }\end{array}$ & $\begin{array}{c}\text { Total } \\
\text { c. d. \% }\end{array}$ & $\begin{array}{c}\text { Total } \\
\text { freq. \% }\end{array}$ \\
\hline Wetter & 47 & 53 & 55 & - & - & - \\
Middle & 29 & 40 & 32 & 20 & 9 & 12 \\
Drier & 24 & 7 & 13 & 80 & 91 & 88 \\
\hline
\end{tabular}

The subject species not shown here: A. subulatus, E. sumatrensis, E. canadensis and $E$. bonariensis.

II. Homogenous habitat segregation of A. subulatus due to the soil moisture. From the results of the field survey mentioned above, it is clear that there is a habitat segregation due to the soil moisture between the communities of $A$. subulatus and Erigeron spp. Namely, the main growing range of $A$. subulatus is always connected with higher moisture. There is often found a pure community of $A$. subu- 
Table V. Chemical components and soil water content of the bed soil

\begin{tabular}{|c|c|c|c|c|c|c|c|c|c|}
\hline \multirow{2}{*}{$\begin{array}{l}\text { Comm- } \\
\text { unity }\end{array}$} & \multirow{2}{*}{$\begin{array}{l}\text { Sampling } \\
\text { portion }\end{array}$} & \multirow{2}{*}{$\begin{array}{c}\text { Total } \\
\text { nitrogen }\end{array}$} & \multirow{2}{*}{$\begin{array}{l}\text { Hu- } \\
\text { mus }\end{array}$} & \multirow[b]{2}{*}{$\mathrm{pH}$} & \multirow[b]{2}{*}{$\mathrm{P}_{2} \mathrm{O}_{5}$} & \multirow[b]{2}{*}{$\mathrm{CaO}$} & \multicolumn{3}{|c|}{ Soil water contents } \\
\hline & & & & & & & $\begin{array}{l}\text { Soon after } \\
\text { a rain-fall }\end{array}$ & $\begin{array}{l}3 \text { days after } \\
\text { a rain-fall }\end{array}$ & Maximum \\
\hline \multirow{5}{*}{ 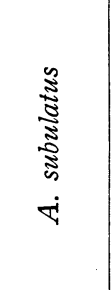 } & $0-5^{\mathrm{cm}}$ & $0.29^{\%}$ & $1.26^{\%}$ & $5.5^{\mathrm{I}}$ & p.p.m. & \multirow{5}{*}{\begin{tabular}{|c|} 
less than \\
0.07 \\
$0.07-0.12$ \\
less than \\
0.07 \\
less than \\
0.07 \\
less than \\
0.07
\end{tabular}} & $19.7^{\%}$ & $17.9^{\%}$ & $38.4^{\%}$ \\
\hline & $5-10$ & 0.22 & 1.88 & 5.5 & 200 & & 19.5 & 15.3 & 39.1 \\
\hline & $10-15$ & 0.22 & 1.66 & 6.5 & 200 & & 19.5 & 16.1 & 44.6 \\
\hline & $15-20$ & 0.14 & 1.32 & 7.0 & 150 & & 20.4 & 16.9 & 48.3 \\
\hline & $20-30$ & 0.10 & 1.12 & 7.0 & 150 & & 20.5 & 19.5 & 51.4 \\
\hline \multirow{5}{*}{ 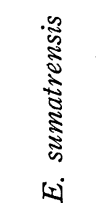 } & $0-5$ & 0.29 & 1.22 & 6.0 & 200 & $0.07-0.12$ & 15.7 & 12.0 & 37.7 \\
\hline & $5-10$ & 0.14 & 1. 17 & 6.3 & 200 & over 0.17 & 16.4 & 12.7 & 36.2 \\
\hline & $10-15$ & 0.07 & 1. 12 & 7.0 & 100 & over 0.17 & 17.5 & 12.5 & 37.6 \\
\hline & $15-20$ & 0.15 & 1.07 & 7.2 & 50 & $0.07-0.12$ & 19.5 & 12.7 & 35.8 \\
\hline & $20-30$ & 0.11 & 1.01 & 7.5 & 20 & $0.07-0.12$ & 18.9 & 13.8 & 39.5 \\
\hline
\end{tabular}

Table VI. Anatomical comparison of subterraneous part of $A$. subulatus from drier and wetter habitat (measuring individual number was 25 in each)

\begin{tabular}{|l|c|c|c|}
\hline \multicolumn{1}{|c|}{ Root form (Habitat) } & S (Drier) & Re or Br (Wetter) & Significancy \\
\hline Root diameter mm & $3.9 \pm 0.34$ & $4.1 \pm 0.42$ & - \\
Cortex thickness $\mu$ & $250 \pm 64$ & $780 \pm 133$ & + \\
Ct. Q. & $14 \pm 3.2$ & $36 \pm 4.6$ & + \\
Diameter of wood parts mm & $2.8 \pm 0.35$ & $2.2 \pm 0.33$ & + \\
Radial number of vessel arrangement & $24 \pm 3.6$ & $20 \pm 4.4$ & + \\
Largest vessel diameter $\mu$ & $106 \pm 29.3$ & $74 \pm 17.9$ & + \\
Smallest vessel diameter & $14 \pm 4.2$ & $14 \pm 5.4$ & - \\
Vessel concentration (in $\left.1 \mathrm{~mm}^{2}\right)$ & $23 \pm 5.4$ & $19 \pm 5.0$ & + \\
Intercellular space in cortex & none & presence & \\
Hardness of wood parts & hard & little soft & \\
\hline
\end{tabular}

Significancy of the differences: - none-significant, + significant at $1 \%$ level

latus where the Erigeron plants can hardly invade*. On the other hand, in the drier stand just adjoined to the wetter ground, a dense community of Erigeron spp. is found. This community is sometimes accompanied by a few individual plants of A. subulatus. With regard to the root form ${ }^{4}$ of $A$. subulatus, it is observed that plants of $A$. subulatus mixed in the Erigeron community show a straight root form (S) in the same manner as in the case of Erigeron spp., but those of A. subulatus in its pure community show a reticulate form (Re) or branched root form (Br) (Fig. 5).

* According to the survey made on the 6 th July, 1953, it was observed that the $A$. subulatus community encountered a flood owing to a long rain for 12 days and that some individuals of the accompaning $E$. sumatrensis and $E$. canadensis suffered several injuries, for example, the leaves were withered and the epidermis of roots were blacked and becoming off. 

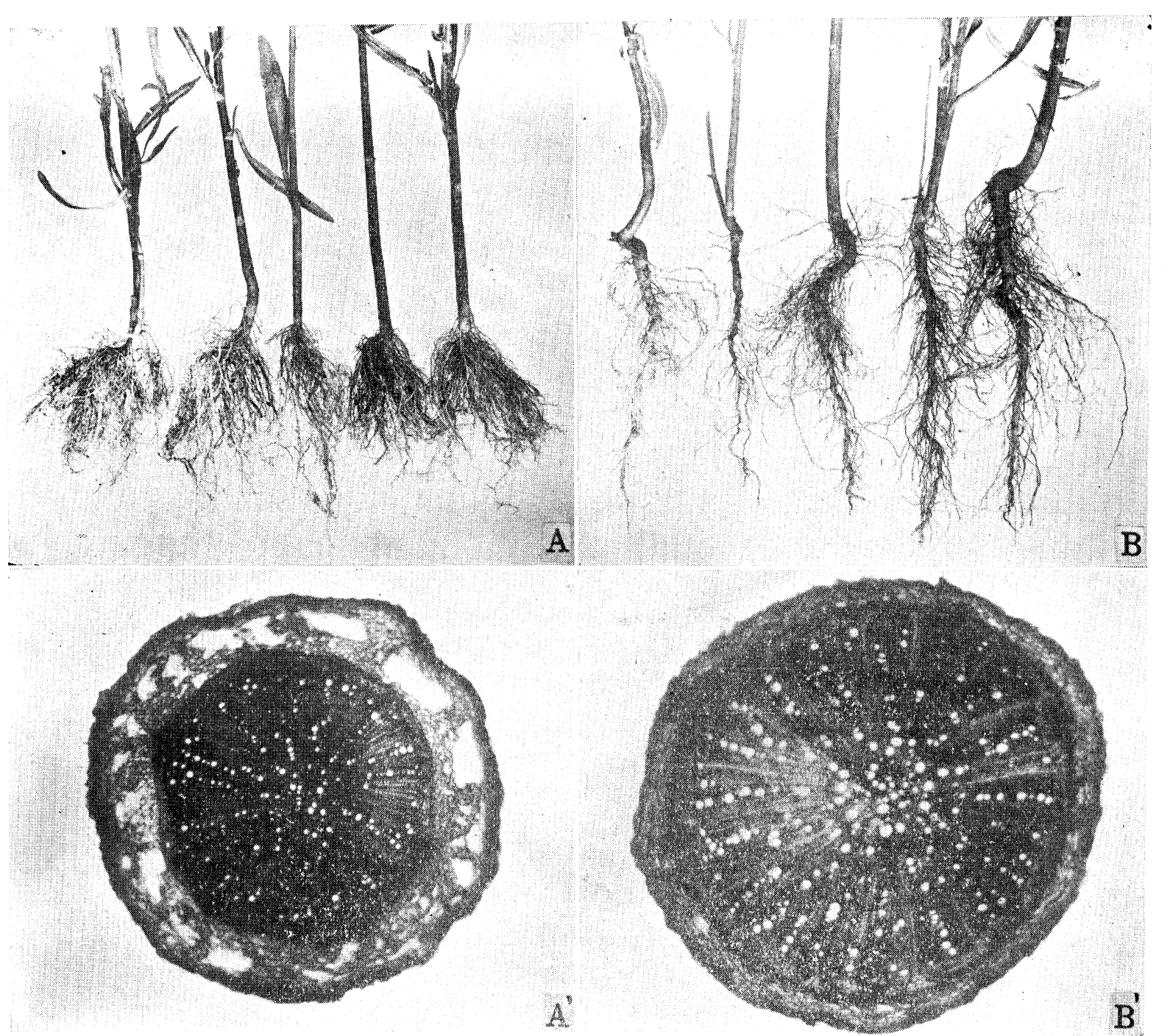

B'

Fig. 5. Showing root form and anatomical features of $A$. subulatus from different habitats. $\mathbf{A}$ from wetter habitat (in its pure community) shows a reticulate root form, and $\mathbf{B}$ from drier habitat (accompaning individuals in E. sumatrensis community) shows a straight form. $\mathbf{A}^{\prime}$ and $\mathbf{B}^{\prime}$ are cross sections of the roots of $\mathbf{A}$ and $\mathbf{B}$ respectively at nearly the same parts in diamter. $\mathbf{A}$ and $\mathbf{B} \times \frac{1}{4}, \mathbf{A}^{\prime}$, and $\mathbf{B}^{\prime} \times \frac{1}{55}$

Furthermore, A. subulatus of the two communities exhibits clear differences in the anatomical features of root such as $\mathbf{C t} . \mathbf{Q}^{*}$, the radial number of vessel arrangements, the diameter of the largest vessels, the diameter of wood parts, the vessel

* Ct.-Q. (=Cortex thickness-Quotient) represents the percentage of the cortex thickness for the root diameter of the same individvals; that is,

$$
\text { Ct.-Q. }=\frac{\text { cortex thickness }}{\text { root radius }} \times 100
$$


concentration, etc. Moreover, remarkable differences are found in regard to the presence of intercellular space in cortex and the hardness of wood parts.

On the relation between the root form and relative abundance in the plants in the treated area, the results as shown in Table VII were obtained.

Table VII. Root form and relative abundance in the plants in the treated area

\begin{tabular}{|l|c|c|c|c|}
\hline \multirow{2}{*}{ Habitat } & \multicolumn{2}{|c|}{ Wetter stand } & \multicolumn{2}{c|}{ Drier stand } \\
\cline { 2 - 5 } Species & Root form & Abundance & Root form & Abundance \\
\hline A. subulatus & $\operatorname{Re}(\mathrm{Br})$ & abundant & $\mathrm{S}$ & seldom present \\
E. sumatrensis & - & - & $\mathrm{S}$ & very abundant \\
E. canadensis & - & - & $\mathrm{S}$ & abundant \\
E. bonariensis & - & - & $\mathrm{S}$ & present \\
\hline
\end{tabular}

\section{Summary}

1. The author experimentally ascertained a heterogenous habitat segregation due to the soil moisture between Aster subulatus and three species of Erigeron, E. sumatrensis, $E$. canadensis and $E$. bonariensis, both of which belong to the same life form and growing period.

2. The main growing range of $A$. subulatus is usually connected with higher soil moisture, but there is found a few individuals of $A$. subulatus accompaning in the community of Erigeron spp. which grows in drier habitat. The root form of $A$. subulatus in the Erigeron community shows a straight root form (S) as well as in the three species of Erigeron. On the other hand, the root form of A. subulatus in its pure community shows a reticulate form (Re) or branched root form (Br).

3. As to the anatomical features of root of $A$. subulatus from both communities, the pure communities of Aster and Erigeron, differences are clearly found in Ct-Q., presence of intercellular space, largest vessel diamter, etc., and the author recognized a homogenous habitat segregation between individuals of $A$. subulatus. Among the plants of Erigeron spp. were not found so notable differences as in Aster subulatus.

\section{References}

1. Arai, M \& Miyahara, M. Agr. \& Hort. 27: 340 (1952) 2. Ellenberg, H. Unkrautgemeinschaften als Zeiger für Klima und Boden, Stuttgart (1950) 3. Horikawa, Y. and Miyawaki, A. Sci. Rep., Yokohama Nat. Univ. S. II, 3: 49 (1954) 4. —— Jap. J. Ecol. 4(2): 79 (1954) 5. Makino, T. Illustrated Flora of Japan, Tokyo (1952) 6. Sshimper, A. und Faber, F. C. Pflanzengeographie auf physiologischer Grundlage, Jena (1935) 7. Warming, E. und Grabner, P. Lehrbuch der ökologischen Pflanzengeographie, Berlin (1933) 8. Yoshihara, K., Kawanabe, S. \& Oda, T. Bull. Nat. Inst. Agr. Sci. S. G., No. 6, 7: 125, 97 (1953) 